\title{
INVOLVEMENT OF LATERAL HABENULA-DORSAL RAPHE NEURONS IN THE DIFFERENTIAL REGULATION OF STRIATAL AND NIGRAL SEROTONERGIC TRANSMISSION IN CATS ${ }^{1}$
}

\author{
TERRY D. REISINE, ${ }^{2}$ PHILIPPE SOUBRIÉ, FRANÇOISE ARTAUD, AND JACQUES GLOWINSKI ${ }^{3}$ \\ Groupe NB, Institut National de la Santé et de la Recherche Médicale (INSERM, U. 114), College de France, 75231 Paris \\ Cedex 5, France
}

Received December 15, 1981; Revised March 5, 1982; Accepted March 8, 1982

\begin{abstract}
The importance of the lateral habenula-dorsal raphe pathway in the control of in vivo $\left[{ }^{3} \mathrm{H}\right]$ serotonin release in the cat basal ganglia was examined using the push-pull cannula technique and an isotopic method for the estimation of $\left[{ }^{3} \mathrm{H}\right]$ serotonin continuously formed from $\left[{ }^{3} \mathrm{H}\right]$ tryptophan. $\left[{ }^{3} \mathrm{H}\right]$ Serotonin was measured in both caudate nuclei and substantiae nigra and, in some cases, in the dorsal raphe. Electrical stimulation of the lateral habenula decreased $\left[{ }^{3} \mathrm{H}\right]$ serotonin release in all structures studied. Blockade of the GABA inhibitory pathway to the lateral habenula by the local application of picrotoxin reduced $\left[{ }^{3} \mathrm{H}\right]$ serotonin release in both substantiae nigra and increased release of the ${ }^{3} \mathrm{H}$-amine in the dorsal raphe but was without effect on $\left[{ }^{3} \mathrm{H}\right]$ serotonin release in either caudate nucleus. This inhibition of nigral $\left[{ }^{3} \mathrm{H}\right]$ serotonin release was antagonized by simultaneous application of picrotoxin to the dorsal raphe. Substance $\mathrm{P}$ delivery to the dorsal raphe produced the same effects on $\left[{ }^{3} \mathrm{H}\right]$ serotonin release as described for picrotoxin application to the lateral habenula except that inhibition of nigral $\left[{ }^{3} \mathrm{H}\right]$ serotonin release was not prevented by local co-administration of picrotoxin. These results suggest that the lateral habenula can control serotonergic transmission in the basal ganglia and that this regulation may be different for those serotonergic neurons innervating the caudate nucleus versus those projecting to the substantia nigra.
\end{abstract}

Anatomical data obtained in the rat and the cat indicate that the dorsal raphe receives an important input from neurons originating or passing through the lateral habenula (Akagi and Powell, 1968; Sakai et al., 1977; Herkenham and Nauta, 1979). It has been suggested that this neuronal input exerts a pronounced control over serotonergic $(5-\mathrm{HT})$ neurons of the dorsal raphe. This hypothesis was proposed since electrical stimulation of the rat lateral habenula decreased the firing rate of $5-\mathrm{HT}$ neurons (Wang and Aghajanian, 1977a; Stern et al., 1979, 1981). In addition, as shown in the cat, the unilateral application of the depolarizing agent, potassium chloride,

\footnotetext{
'This study was supported by grants from the Institut National de la Santé et de la Recherche Médicale, Direction des recherches, etudes et Techniques (81.050), and Rhône-Poulenc S. A. T. D. R. is a National Institute of Neurological and Communicative Disorders and Stroke Fellow (Grant 1 F32 NS 064.67.01).

${ }^{2}$ Present address: Laboratory of Clinical Science, National Institute of Mental Health, Bethesda, MD 20205.

${ }^{3}$ To whom correspondence should be addressed at Groupe NB, Institut National de la Santé et de la Recherche Médicale U.114, Collège de France, 11 Place Marcelin Berthelot, 75231 Paris Cedex 5, France.
}

to the lateral habenula altered the in vivo release of 5HT in brain structures which receive a 5-HT innervation from the dorsal raphe (Soubrié et al., 1981b). The present study was undertaken to explore further in the cat the role of the lateral habenula in controlling the activity of 5-HT neurons projecting to the caudate nucleus and/or to the substantia nigra (Bobillier et al., 1976; Taber Pierce et al., 1976). To this end, using the push-pull cannula technique and an isotopic method (Reisine et al., 1982a), we compared the effects of various treatments made at different levels of the habenula-raphe axis on the in vivo nigral and striatal $\left[{ }^{3} \mathrm{H}\right] 5-\mathrm{HT}$ release. Changes induced by the unilateral electrical stimulation of the lateral habenula were investigated first. Since the cat lateral habenula receives an input from the entopeduncular nucleus (Larsen and McBride, 1979; McBride, 1981) and since experiments performed in rodents (Nagy et al., 1978) have suggested that this projection is GABAergic, we then examined the effects of picrotoxin infusion into the lateral habenula. Furthermore, since it has been proposed that the rat lateral habenula-dorsal raphe pathway contains substance $P$ neurons (Neckers et al., 1979; Vincent et al., 1980), we also investigated the pussible 
alterations in nigral and striatal $\left[{ }^{3} \mathrm{H}\right] 5-\mathrm{HT}$ release induced by substance $\mathrm{P}$ application to the dorsal raphe. Finally, because the inhibition of the dorsal raphe neurons induced by the electrical stimulation of the lateral habenula has been found to be reduced by intradorsal raphe application of picrotoxin (Wang and Aghajanian, 1977a), attempts were made to determine whether two of our manipulations, picrotoxin application to the lateral habenula and substance $\mathrm{P}$ delivery to the dorsal raphe, could influence $\left[{ }^{3} \mathrm{H}\right] 5$-HT release in the basal ganglia by way of GABA neurons impinging on the 5-HT cells of the dorsal raphe.

The results obtained confirm the role of the lateral habenula in controlling bilaterally 5-HT transmission in structures of the basal ganglia. Moreover, they indicate that some of the neurons originating from the lateral habenula can contribute selectively to the regulation of 5-HT release in both substantiae nigra.

\section{Materials and Methods}

Animals and surgery. The release of $\left[{ }^{3} \mathrm{H}\right] 5-\mathrm{HT}$ was studied in cats of either sex lightly anesthetized with halothane $(1.2 \%)$. The techniques used have been described extensively (Héry et al., 1979). Briefly, surgery and stereotaxic fixation of the head with two steel pieces fixed by acrylic resin in the frontal sinus and on the occipital bone to avoid nociceptive stimulation and implantation of push-pull cannulae were performed under $3 \%$ halothane anesthesia. Alveolar $\mathrm{CO}_{2}$, femoral blood pressure, heart rate, and body temperature were monitored continuously.

Push-pull cannulae were implanted stereotaxically into each caudate nucleus and substantia nigra, the left lateral habenula, and also the dorsal raphe nucleus (Snider and Niemer, 1961). For the caudate nucleus $(\mathrm{A}=14.5 ; \mathrm{L}=$ $\pm 5 ; \mathrm{H}=+5)$, angular approaches were used $\left(30^{\circ}\right.$ in the frontal plane). The localization of the placements are revealed in Figure 1. For the substantia nigra $(\mathrm{A}=+4 ; \mathrm{L}$ $= \pm 4 ; \mathrm{H}=-3)$, angular approaches also were used $\left(30^{\circ}\right.$ in the frontal plane and $20^{\circ}$ in the sagittal plane) in order to avoid the lateral ventricle and nigral efferents and afferents. One cannula or one stimulating electrode also was positioned $\left(40^{\circ}\right.$ in the frontal plane) in the lateral habenula $(\mathrm{A}=7.5 ; \mathrm{L}=2 ; \mathrm{H}=+4.5)$ using two different and successive approaches in order to minimize brain damage. The distribution of the localizations of the cannula or electrode tip within the lateral habenula is shown in Figure 2. Finally, in some cases, a cannula was introduced $\left(15^{\circ}\right.$ in the frontal plane and $40^{\circ}$ in the sagittal plane) into the dorsal raphe $(\mathrm{A}=-1.5 ; \mathrm{L}=0 ; \mathrm{H}=-2)$ in order to reach midline cells. Histological controls of the localization of the tip of each push-pull cannula were made after each experiment. For the studies employing a stimulating electrode in the lateral habenula, the electrode tip was marked by creating a small lesion in the habenula after passing a 5-mA current for $15 \mathrm{sec}$ through the electrode.

Estimation of $\left[{ }^{3} \mathrm{H}\right] 5-\mathrm{HT}$ release. An artificial cerebrospinal fluid (in millimolar concentrations: $\mathrm{NaCl}, 126.5$; $\mathrm{NaHCO}_{3}, 27.5 ; \mathrm{KCl}, 2.4 ; \mathrm{KH}_{2} \mathrm{PO}_{4}, 0.5 ; \mathrm{CaCl}_{2}, 1.1 ; \mathrm{MgCl}_{2}$, $0.85 ; \mathrm{Na}_{2} \mathrm{SO}_{4}, 0.5$; glucose, 5.9 adjusted to $\mathrm{pH} 7.3$ with an
$\mathrm{O}_{2}: \mathrm{CO}_{2} 95: 5 \mathrm{v} / \mathrm{v}$ mixture) containing 40 to $50 \mu \mathrm{Ci} / \mathrm{ml}$ of purified L- $\left[{ }^{3} \mathrm{H}\right]$ tryptophan $(20$ to $30 \mathrm{Ci} / \mathrm{mmol}$, Amersham-France) or L-[side chain $\left.2,3-{ }^{3} \mathrm{H}(\mathrm{N})\right]$ tryptophan $(10$ to $20 \mathrm{Ci} / \mathrm{mmol}$, New England Nuclear) was delivered to each push-pull cannula at a constant rate of $0.5 \mathrm{ml} / 12$ min and superfusate fractions $(12 \mathrm{~min})$ were collected in tubes containing 5-HT $(2 \mu \mathrm{g})$, tryptamine $(2 \mu \mathrm{g})$, and tryptophan $(20 \mu \mathrm{g}) .{ }^{3} \mathrm{H}$-Indoleamines released into the superfusates were separated from $\left[{ }^{3} \mathrm{H}\right]$ tryptophan and ${ }^{3} \mathrm{H}$-metabolites by successive ion exchange chromatography on Dowex AG50 WX4 microcolumns and Amberlite CG 50 columns. $\left[{ }^{3} \mathrm{H}\right]$ Tryptamine present with $\left[{ }^{3} \mathrm{H}\right] 5$ HT after the Amberlite elution with sodium borate buffer (pH 10) was removed using benzene; the amount of $\left[{ }^{3} \mathrm{H}\right]$ 5 -HT was finally estimated by liquid scintillation spectrophotometry.

Under these conditions, the spontaneous release of $\left[{ }^{3} \mathrm{H}\right] 5-\mathrm{HT}$ rapidly reached a steady state level after the onset of labeling with $\left[{ }^{3} \mathrm{H}\right]$ tryptophan; the quantities of $\left[{ }^{3} \mathrm{H}\right] 5-\mathrm{HT}$ released were about 6 to 8 times the blank values $(<0.25 \mathrm{nCi})$ in the caudate nucleus or substantia nigra and about 12 to 15 times the blank value in the dorsal raphe. Cerebrospinal fluid without $\left[{ }^{3} \mathrm{H}\right]$ tryptophan was applied to the lateral habenula.

Treatments. The various treatments usually were carried out $136 \mathrm{~min}$ after the onset of the superfusion with $\left[{ }^{3} \mathrm{H}\right]$ tryptophan. Substance $\mathrm{P}\left(10^{-7} \mathrm{M}\right)$ was delivered to the dorsal raphe for a total of $24 \mathrm{~min}$ (two fractions); picrotoxin $\left(10^{-5} \mathrm{M}\right)$ was applied to the lateral habenula for $48 \mathrm{~min}$ (four fractions) and to the dorsal raphe for either $48 \mathrm{~min}$ (during picrotoxin application to the lateral habenula) or $24 \mathrm{~min}$ (during the delivery of substance $P$ to the dorsal raphe). The concentrations of picrotoxin and substance $P$ were similar to those employed in previous studies (Soubrié et al., 1981a; Reisine et al., 1982b).

For the electrical stimulation of the lateral habenula, cathodal square pulses $(0.5 \mathrm{~mA}, 0.5 \mathrm{msec}, 1.5 \mathrm{~Hz})$ were delivered for $12 \mathrm{~min}$ by an Anapulse $302 \mathrm{~T}$ stimulator through a bipolar electrode. The diameter of the tip of the electrode was $0.4 \mathrm{~mm}$ and the length from the tip to the insulation was $0.6 \mathrm{~mm}$. The parameters of stimulation were selected according to electrophysiological studies (Wang and Aghajanian, 1977a; Stern et al., 1979, 1981).

Statistical analysis. The mean value of $\left[{ }^{3} \mathrm{H}\right] 5-\mathrm{HT}$ measured in the four fractions collected after a 90-min labeling period was estimated in the superfusates of each push-pull cannula and used as the control value $(100 \%)$. The $\left[{ }^{3} \mathrm{H}\right] 5-\mathrm{HT}$ content in each successive fraction was then expressed as a percentage of this base line value both in control cats and in cats subjected to treatments. This procedure allowed us to determine the mean \pm SEM of results obtained in $N$ experiments and to analyze statistically the differences in the quantity of $\left[{ }^{3} \mathrm{H}\right] 5-\mathrm{HT}$ released in corresponding fractions of control and treated cats using the Student's $t$ test. When the $p$ value was $<0.05$, the difference was considered significant.

A two-way analysis of variance was used in order to analyze the action of a simultaneous application of picrotoxin to the dorsal raphe on the effects caused by application of either picrotoxin to the lateral habenula or substance $\mathbf{P}$ to the dorsal raphe. 


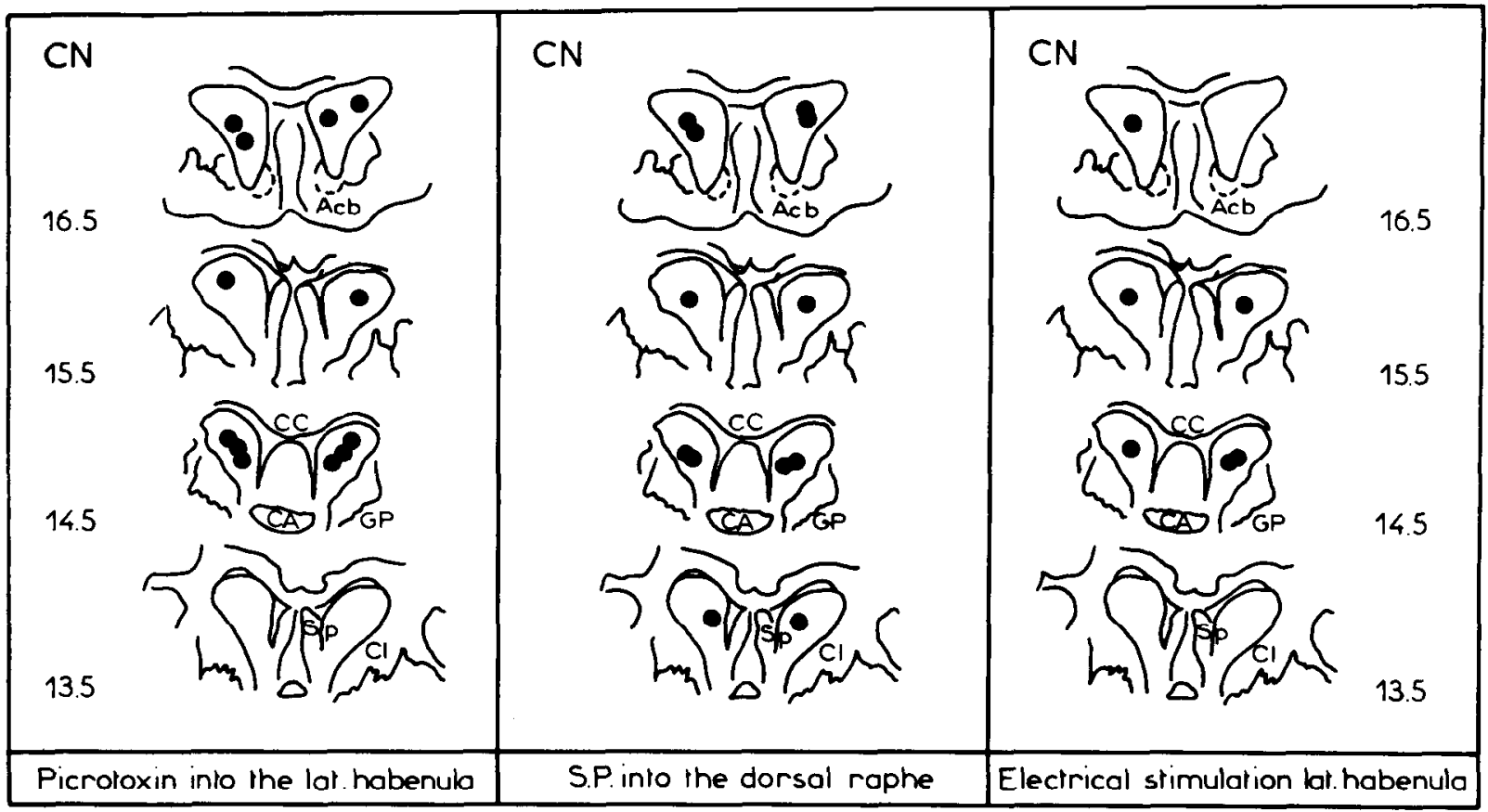

Figure 1. Localization of push-pull cannula tips within either cat caudate nucleus $(C N)$ under each of the three experimental conditions: picrotoxin $\left(10^{-5} \mathrm{M}\right)$ into the lateral habenula, substance $\mathrm{P}(S . P).\left(10^{-7} \mathrm{M}\right)$ into the dorsal raphe, and electrical stimulation of the lateral habenula. The schematic diagrams of the caudate nucleus were based on those of Snider and Niemer (1961). $A c b$, Nucleus accumbens; $C A$, commissura anterior; $C C$, corpus callosum; $C I$, capsula interna; $G P$, globus pallidus; $S p$, area septalis.

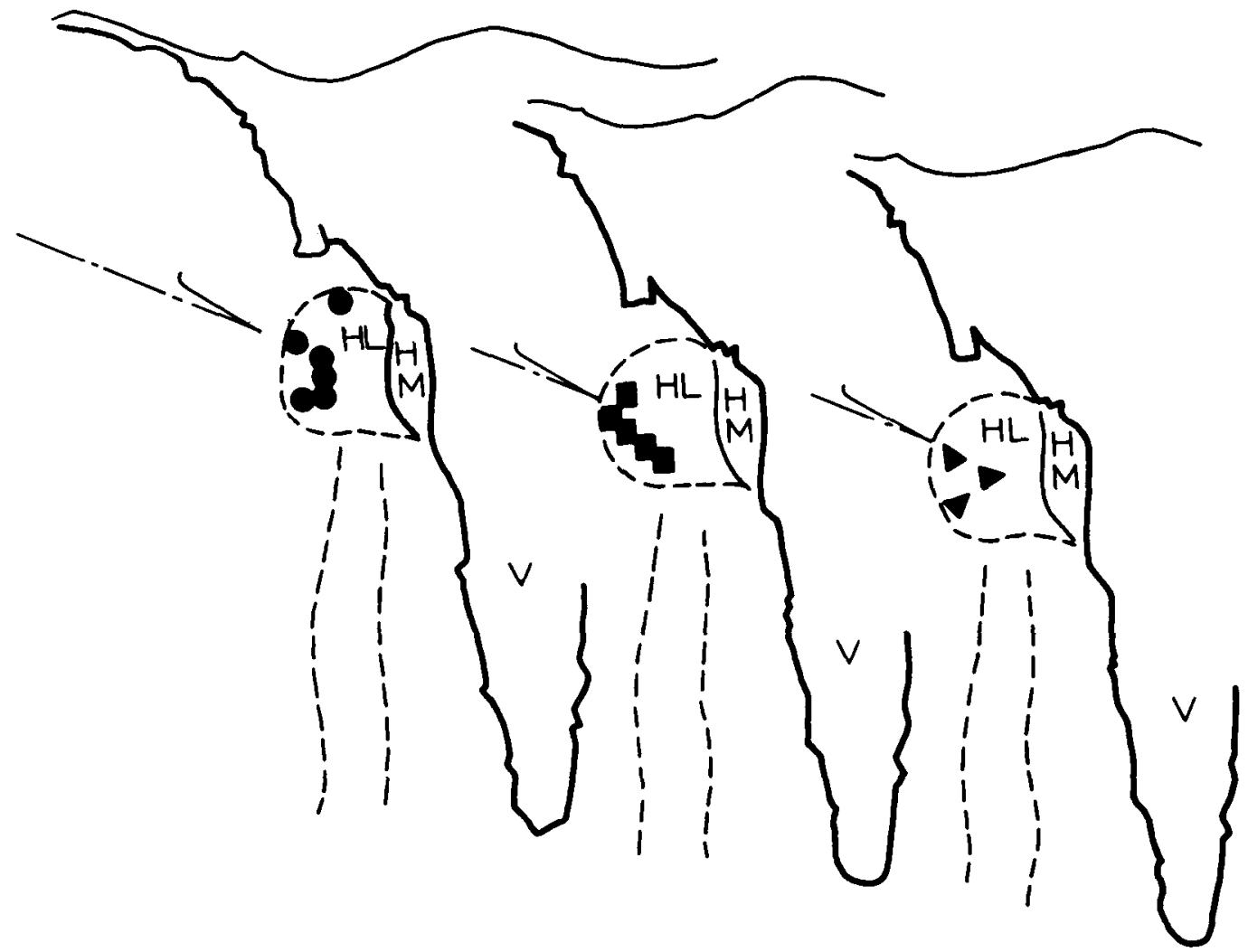

Figure 2. Localization of the tip of the push-pull cannula or the stimulating electrode inserted into the left lateral habenula of cats subjected to the following experimental conditions: picrotoxin $\left(10^{-5} \mathrm{M}\right)$ into the lateral habenula $(0)$, picrotoxin $\left(10^{-5} \mathrm{M}\right)$ into the lateral habenula and picrotoxin $\left(10^{-5} \mathrm{M}\right)$ into the dorsal raphe $(\square)$, and electrical stimulation of the lateral habenula $(\boldsymbol{\Delta})$. The localizations revealed on the schematic diagram (anteriority $=7$ ) which was based on that of Snider and Niemer (1961) are distributed within an anteriority ranging from 6.5 to 7.5. The arrow indicates the angular direction of the cannula or the electrode inside of the brain. $H L$, nucleus habenulae lateralis; $H M$, nucleus habenulae medialis; $V$, third ventricle. 


\section{Results}

Effects of the unilateral electrical stimulation of the lateral habenula on $\left.{ }^{3} \mathrm{H}\right] 5-\mathrm{HT}$ release in both caudate nuclei and substantiae nigra. The unilateral electrical stimulation of the left lateral habenula for $12 \mathrm{~min}(0.5$ $\mathrm{mA}, 0.5 \mathrm{msec}, 1.5 \mathrm{~Hz}$ ) induced a significant reduction of $\left[{ }^{3} \mathrm{H}\right] 5-\mathrm{HT}$ release in both caudate nuclei and substantiae nigra (Fig. 3). This effect was observed only during the stimulation in the left caudate nucleus and in the fraction immediately following in the three other basal ganglion structures. In all cases, $\left[{ }^{3} \mathrm{H}\right] 5-\mathrm{HT}$ release returned to base line levels 24 min (two fractions) after the stimulation. In two experiments, the initial electrical stimulation was followed $2 \mathrm{hr}$ later by a second 12-min stimulation of the lateral habenula. This second manipulation produced the same effects on $\left[{ }^{3} \mathrm{H}\right] 5-\mathrm{HT}$ release in the four structures as the first stimulation.

In three experiments, the release of $\left[{ }^{3} \mathrm{H}\right] 5$-HT also was estimated in the dorsal raphe (Table I). The electrical stimulation of the lateral habenula induced an immediate significant decrease $(22 \%)$ in $\left[{ }^{3} \mathrm{H}\right] 5-\mathrm{HT}$ release in this latter structure.

The localization of the tip of the stimulating electrode in all of these experiments is illustrated in Figure 2.

Effects of the unilateral application of picrotoxin $\left(10^{-5}\right.$ M) to the lateral habenula on $\left[{ }^{3} \mathrm{H}\right] 5-\mathrm{HT}$ release in both caudate nuclei and substantiae nigra. The 48-min application (four fractions) of the GABA antagonist picrotoxin $\left(10^{-5} \mathrm{M}\right)$ to the left lateral habenula induced an

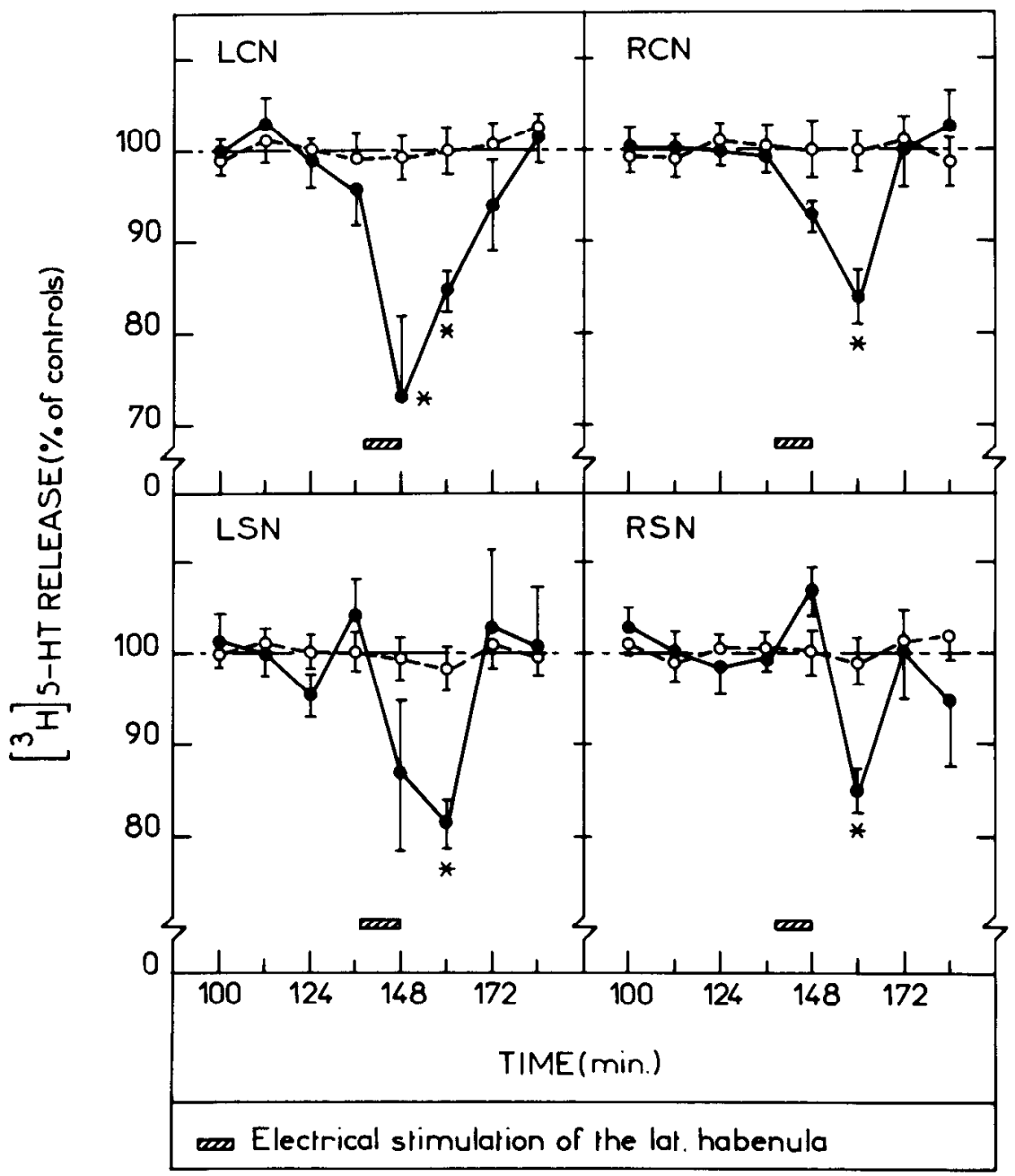

Figure 3. Effects of electrical stimulation of the left lateral habenula on $\left[{ }^{3} \mathrm{H}\right]$ serotonin release in the caudate nucleus and substantia nigra. Using push-pull cannula, both left and right caudate nuclei ( $L C N$ and $R C N)$ and left and right substantiae nigra ( $L S N$ and $R S N$ ) were superfused continuously with an artificial cerebrospinal fluid medium containing $L-\left[{ }^{3} \mathrm{H}\right]$ tryptophan as described under "Materials and Methods." $\left[{ }^{3} \mathrm{H}\right] 5$-HT release was estimated in 12 -min successive superfusate fractions. A stimulating electrode also was placed into the left lateral habenula. An electrical stimulation $(0.5 \mathrm{~mA}, 0.5 \mathrm{msec}, 1.5 \mathrm{~Hz})$ was applied for 12 $\mathrm{min}, 136 \mathrm{~min}$ after the onset of the delivery of $\left[{ }^{3} \mathrm{H}\right]$ tryptophan to each basal ganglion structure. $\left[{ }^{3} \mathrm{H}\right] 5-\mathrm{HT}$ in each fraction was expressed as a percentage of the average release from the four 12-min fractions collected after a 90 -min labeling period. Data are the mean \pm SEM of results obtained in three treated cats (O) and four control animals $(O) . *, p<0.05$ when compared with corresponding control values. 
TABLE I

$\left[{ }^{3} \mathrm{HJ5}-\mathrm{HT}\right.$ release in the dorsal raphe

Electrical stimulation (for $12 \mathrm{~min}$ ), picrotoxin application (for $48 \mathrm{~min}$ ) to the lateral habenula, and substance $\mathrm{P}$ delivery (for $24 \mathrm{~min}$ ) to the dorsal raphe were carried out $136 \mathrm{~min}$ after the onset of delivery of $\left[{ }^{3} \mathrm{H}\right]$ tryptophan to the dorsal raphe. $\left[{ }^{3} \mathrm{H}\right] 5-\mathrm{HT}$ was estimated in successive superfusate fractions. The base line level of release was determined from the four fractions of $\left[{ }^{3} \mathrm{H}\right] 5-\mathrm{HT}$ release preceding the treatment. Control values were obtained from untreated animals. Values during the treatment period are presented as a percentage of spontaneous release. Three animals were used in each experiment.

\begin{tabular}{|c|c|c|c|c|}
\hline & Controls & $\begin{array}{l}\text { Electrical Stimulation } \\
\text { of I,ateral Habenula }\end{array}$ & $\begin{array}{l}\text { Picrotoxin }\left(10^{-5} \mathrm{M}\right) \\
\text { Application to } \\
\text { Lateral Habenula }\end{array}$ & $\begin{array}{c}\text { Substance } \mathrm{P}\left(10^{-7} \mathrm{M}\right) \\
\text { Application to } \\
\text { Dorsal Raphe }\end{array}$ \\
\hline $\begin{array}{l}\text { Base line } \\
\text { (average of four fractions) }\end{array}$ & $100 \pm 4$ & $100 \pm 4$ & $100 \pm 5$ & $100 \pm 8$ \\
\hline \multicolumn{5}{|l|}{ Treatment } \\
\hline $1^{\circ}$ fraction & $102 \pm 4$ & $78 \pm 3^{a}$ & $122 \pm 4^{a}$ & $155 \pm 15^{a}$ \\
\hline $2^{\circ}$ fraction & $104 \pm 3$ & $80 \pm 6^{a}$ & $119 \pm 7$ & $156 \pm 22$ \\
\hline
\end{tabular}

" $p<0.05$ compared to controls.

immediate and significant decrease in $\left[{ }^{3} \mathrm{H}\right] 5$-HT release in both substantiae nigra (Fig. 4). These effects, which were similar in amplitude $(-25 \%)$ to those observed under the electrical stimulation, persisted during the entire period of the drug application and were even detected in the left substantia nigra after the drug removal. In contrast to that observed after the electrical stimulation, no significant change in $\left[{ }^{3} \mathrm{H}\right] 5-\mathrm{HT}$ release was observed in either caudate nucleus during or after picrotoxin application to the lateral habenula. In one experiment, picrotoxin $\left(10^{-5} \mathrm{M}\right)$ was applied to the lateral habenula (for $48 \mathrm{~min}$ ) twice at an interval of $2 \mathrm{hr}$. The effects of each of these applications on $\left[{ }^{3} \mathrm{H}\right] 5-\mathrm{HT}$ release in each substantia nigra were similar. In three experiments, $\left[{ }^{3} \mathrm{H}\right] 5-\mathrm{HT}$ release also was measured in the dorsal raphe (Table I). The application of picrotoxin to the lateral habenula induced an immediate and significant increase in $\left[{ }^{3} \mathrm{H}\right] 5-\mathrm{HT}$ release $(22 \%)$ in this structure.

The localization of the tip of the push-pull cannula introduced into the lateral habenula in the various experiments (six cats) is illustrated in Figure 2. It should be pointed out that the lack of change in $\left[{ }^{3} \mathrm{H}\right] 5-\mathrm{HT}$ release in the caudate nucleus was observed no matter what the site of superfusion in this structure (Fig. 1). Furthermore, in two additional cats, the push-pull cannula tips were placed in positions more anterior $(A=17.5 ; 18)$ than the normal caudate nucleus placement site. In these cases, picrotoxin applied to the lateral habenula still did not alter $\left[{ }^{3} \mathrm{H}\right] 5$-HT release in either caudate nucleus.

Effects of the application of substance $P\left(10^{-7} \mathrm{M}\right)$ to the dorsal raphe on $\left[^{3} \mathrm{H}\right] 5-\mathrm{HT}$ release in both caudate nuclei and substantiae nigra. Since there is some indication that substance $P$ in the dorsal raphe could originate from the habenula (Neckers et al., 1979; Vincent et al., 1980), the effects of the local application of substance $\mathrm{P}\left(10^{-7} \mathrm{M}\right)$ to the dorsal raphe also were examined. When applied for $24 \mathrm{~min}$ (two fractions) to the dorsal raphe, substance $\mathrm{P}$ induced an immediate, significant decrease $(20 \%)$ of $\left[{ }^{3} \mathrm{H}\right] 5-\mathrm{HT}$ release in both substantiae nigra (Fig. 5 ). These effects, which persisted during the entire period of the peptide's application, were even seen in the two following fractions in the left substantia nigra after the removal of substance $P$ from the superfusion fluid. $\left[{ }^{3} \mathrm{H}\right]$ 5 -HT release in both substantiae nigra returned to base line levels approximately $1 \mathrm{hr}$ after the termination of the substance $P$ application. As observed during the application of picrotoxin to the lateral habenula, no significant changes in $\left[{ }^{3} \mathrm{H}\right] 5-\mathrm{HT}$ release occurred in either caudate nucleus during or after the substance $\mathrm{P}$ application to the dorsal raphe (Fig. 5) regardless of the site of superfusion in these structures (Fig. 1).

Substance $\mathrm{P}\left(10^{-7} \mathrm{M}\right)$ also induced a local effect, since an immediate significant increase in $\left[{ }^{3} \mathrm{H}\right] 5-\mathrm{HT}$ release (55\%) was observed in the dorsal raphe (Table I).

In all of these experiments, the placement of the cannula tip supplying substance $P$ was within the dorsal raphe.

Selective blockade by the application of picrotoxin $\left(10^{-5} \mathrm{M}\right)$ to the dorsal raphe of the changes in nigral $\left[{ }^{3} \mathrm{H}\right] 5-\mathrm{HT}$ release induced by inhibition of GABA transmission in the lateral habenula. These experiments were performed to determine the mechanisms involved in the inhibitory action on nigral $\left[{ }^{3} \mathrm{H}\right] 5-\mathrm{H}$ T release induced by the unilateral application of picrotoxin $\left(10^{-5} \mathrm{M}\right)$ to the lateral habenula and by the application of substance $P$ $\left(10^{-7} \mathrm{M}\right)$ to the dorsal raphe. For this purpose, both types of treatments were repeated during blockade of GABAergic transmission in the dorsal raphe. An analysis of variance revealed that the simultaneous local application of picrotoxin $\left(10^{-5} \mathrm{M}\right)$ to the dorsal raphe significantly attenuated ( $p<0.05$, left substantia nigra; $p<$ 0.02 , right substantia nigra) the inhibition of $\left[{ }^{3} \mathrm{H}\right] 5-\mathrm{HT}$ release in both substantiae nigra induced by the application of picrotoxin to the left lateral habenula (Fig. 1). However, picrotoxin applied to the dorsal raphe did not alter $(p>0.05)$ the changes in $\left[{ }^{3} \mathrm{H}\right] 5-\mathrm{HT}$ release elicited by substance $P$ (Fig. 5). The application of picrotoxin alone to the dorsal raphe did not modify the release of $\left[{ }^{3} \mathrm{H}\right] 5-\mathrm{HT}$ in either substantia nigra significantly (data not shown).

\section{Discussion}

The present study has revealed three important aspects of central 5-HT transmission: (1) the lateral habenula can exert a pronounced control of 5-HT release from neurons of raphe origin which project to the basal ganglia, (2) the transmitter(s) associated with the lateral habenula-dorsal raphe pathway may be GABA and/or substance $\mathrm{P}$, and (3) 5-HT neurons innervating the caudate nucleus may be controlled differently at the level of 


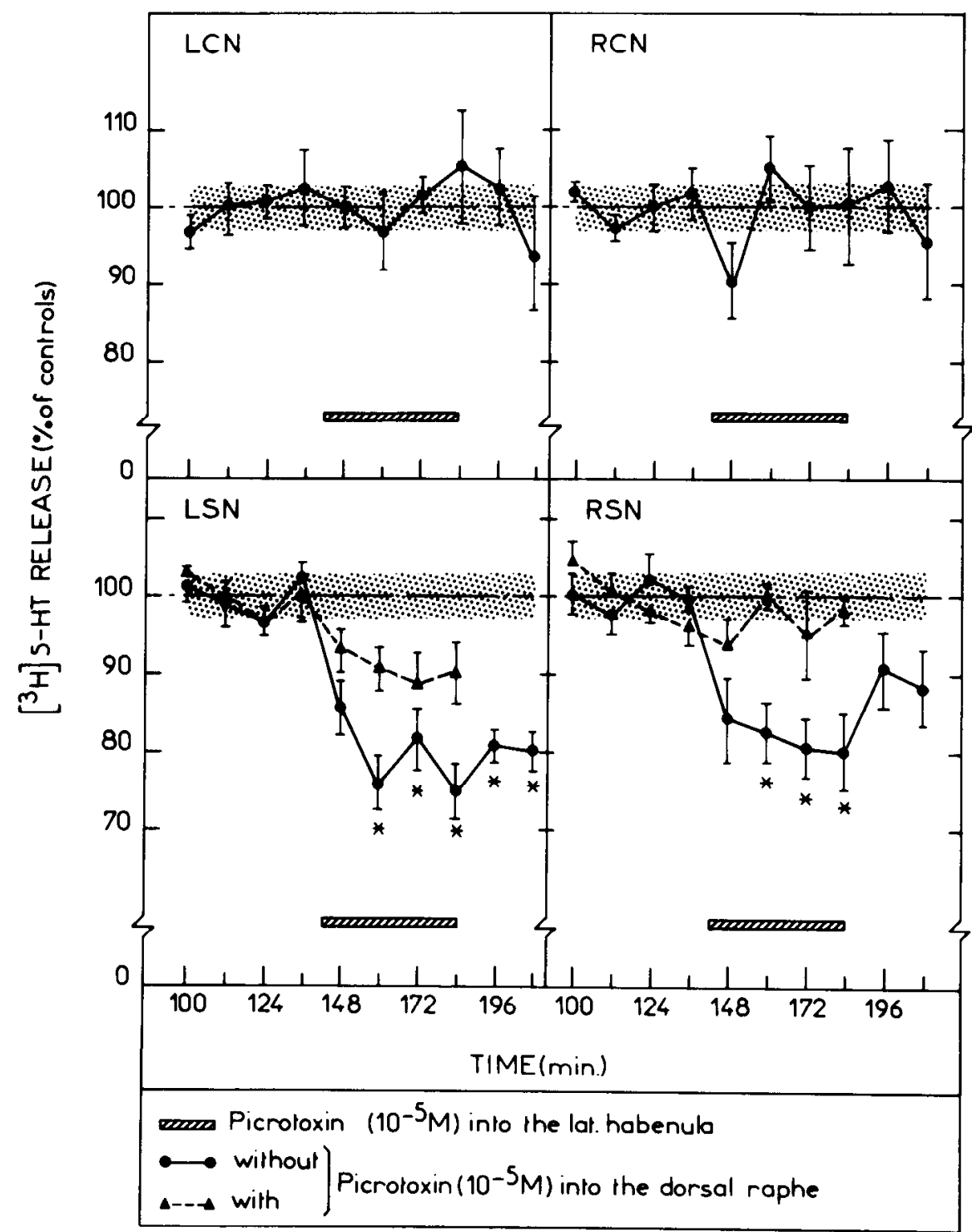

Figure 4. Effects of unilateral application of picrotoxin to the left lateral habenula on $\left[{ }^{3} \mathrm{H}\right] 5-\mathrm{HT}$ release in both caudate nuclei and substantiae nigra. Picrotoxin $\left(10^{-5}\right.$ M) was applied for $48 \mathrm{~min}$ to the left lateral habenula (by way of a push-pull cannula) $136 \mathrm{~min}$ after the onset of the delivery of $\left[{ }^{3} \mathrm{H}\right]$ tryptophan to each basal ganglion structure (both left and right caudate nuclei ( $L C N$ and $R C N$ ) and substantiae nigra $(L S N$ and $R S N)$ ). Data are the means \pm SEM of results obtained in six treated cats (O) and four controls (stippled area). *,p $<0.05$ when compared with corresponding control values. In another series of experiments, picrotoxin $\left(10^{-5} \mathrm{M}\right)$ was applied simultaneously to the left lateral habenula and dorsal raphe for $48 \mathrm{~min}, 136 \mathrm{~min}$ after the onset of the delivery of $\left[{ }^{3} \mathrm{H}\right]$ tryptophan to each substantia nigra. Data are the means \pm SEM of results obtained in five cats treated in this manner $(\Delta)$.

the dorsal raphe from those terminating in the substantia nigra.

Previous studies have shown that electrical stimulation of the rat lateral habenula can decrease the firing rate of dorsal raphe 5-HT cells (Wang and Aghajanian, 1977a; Stern et al., 1979, 1981). Similarly, we found that unilateral electrical stimulation of the cat lateral habenula reduced $\left[{ }^{3} \mathrm{H}\right] 5-\mathrm{HT}$ release from terminals of dorsal raphe neurons in both caudate nuclei and substantiae nigra. Furthermore, blockade of the inhibitory GABAergic input (perhaps of entopeduncular origin (Larsen and McBride, 1979; McBride, 1981) by picrotoxin application into the lateral habenula induced a decrease in $\left[{ }^{3} \mathrm{H}\right] 5-\mathrm{HT}$ release in both substantiae nigra. These results imply that activation of neurons (and fibers) of the lateral habenula can inhibit and therefore control the activity of 5-HT neurons innervating the basal ganglia.

Wang and Aghajanian (1977a) have proposed that GABA could be a transmitter of the rat lateral habenuladorsal raphe pathway. This was suggested from the finding that the iontophoretic application of picrotoxin to the dorsal raphe blocked the inhibition of dorsal raphe cells elicited by electrical stimulation of the lateral habenula. The present results are in agreement with those of Wang 


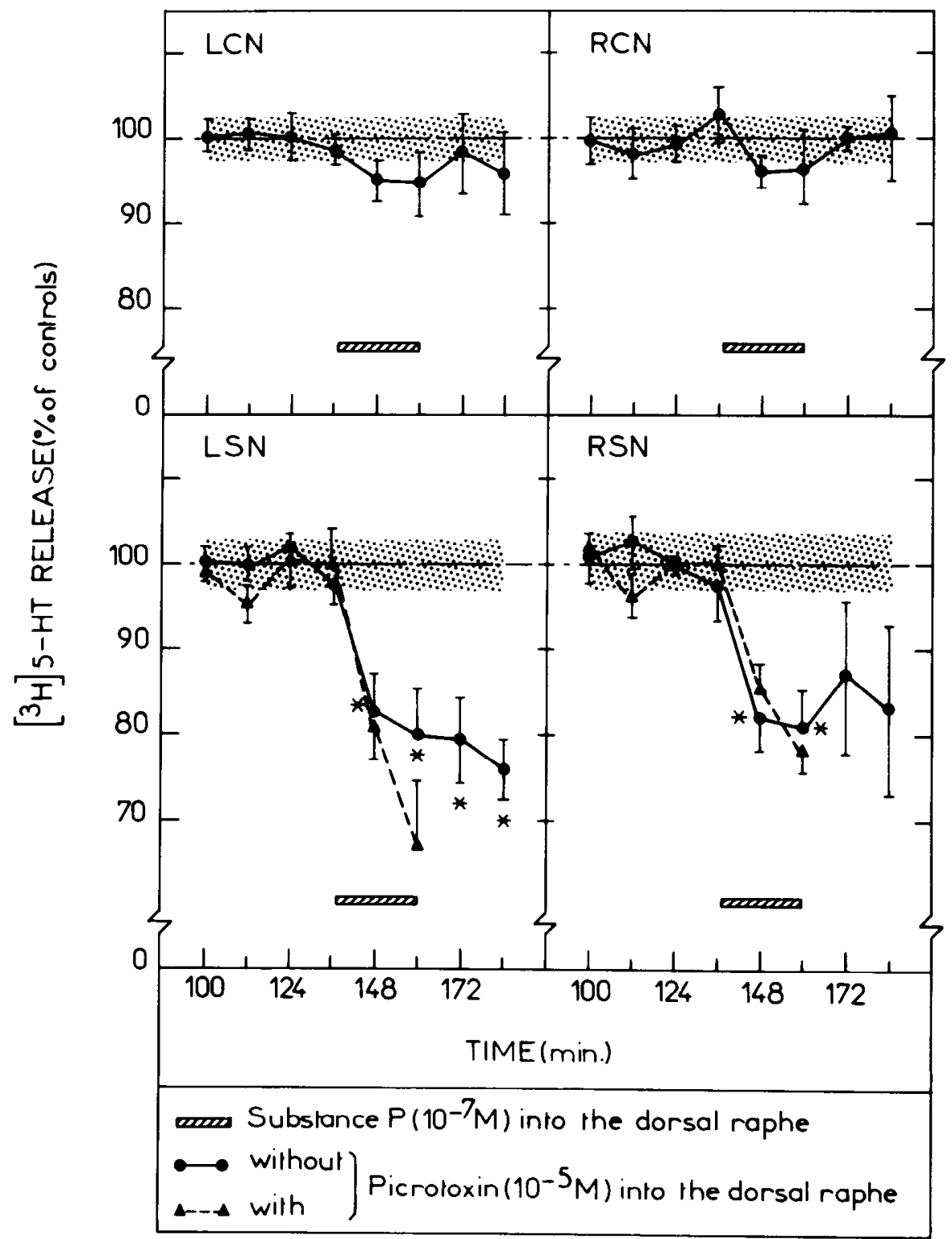

Figure 5. Effect of the application of substance $\mathrm{P}$ to the dorsal raphe on $\left.{ }^{3} \mathrm{H}\right] 5$-IIT release in both caudate nuclei and substantiae nigra. Substance $P\left(10^{-7} \mathrm{M}\right)$ was applied for $24 \mathrm{~min}$ to the dorsal raphe (by way of a push-pull cannula) $136 \mathrm{~min}$ after the onset of the delivery of $\left[{ }^{3} \mathrm{H}\right]$ tryptophan to each basal ganglion structure (both left and right caudate nuclei ( $L C N$ and $R C N$ ) and substantiae nigra ( $L C N$ and $R S N)$. Data are the means \pm SEM of results obtained in six treated cats $(O)$ and four controls (stippled area). $*, p<0.05$ when compared with corresponding control values. In another series of experiments, substance $P\left(10^{-7} \mathrm{M}\right)$ and picrotoxin $\left(10^{-5}\right.$ M) were applied simultaneously to the dorsal raphe for $48 \mathrm{~min}, 136 \mathrm{~min}$ after the onset of the delivery of $\left[{ }^{3} \mathrm{H}\right]$ tryptophan to each substantia nigra. Data are the means \pm SEM of results obtained in five cats treated in this manner (A).

and Aghajanian (1977a) since the simultaneous application of picrotoxin to the dorsal raphe prevented the inhibition of nigral $\left[{ }^{3} \mathrm{H}\right] 5-\mathrm{HT}$ release induced by the delivery of the GABA antagonist to the lateral habenula. Thus, in cats, changes in GABA transmission within the dorsal raphe seem to play an important role in the alterations of $\left[{ }^{3} \mathrm{H}\right] 5-\mathrm{HT}$ release observed in the basal ganglia following lateral habenula manipulations. This statement is reinforced further by in vivo release studies which have shown that the application of GABA to the cat dorsal raphe reduces striatal 5-HT release (Héry and
Ternaux, 1981). The presence of a direct GABAergic lateral habenula-dorsal raphe pathway proposed by Wang and Aghajanian (1977a) has been questioned by several authors. Indeed, studies performed in the rat have indicated that lesions of the lateral habenula do not produce the expected alterations in glutamic acid decarboxylase activity (a marker for GABA neurons) in the dorsal raphe (Gottesfeld et al., 1978; Belin et al., 1979; Neckers et al., 1979). This has led to the proposal that non-GABAergic lateral habenula-dorsal raphe neurons can activate GABA interneurons in the dorsal raphe 
which could be involved in the control of 5-HT neurons (Neckers et al., 1979). Such an anatomical organization could explain the results of Wang and Aghajanian (1977a) as well as our own observations on the antagonism of the effects of picrotoxin application to the lateral habenula by the blockade of GABAergic transmission in the cat dorsal raphe.

According to Stern et al. (1981), picrotoxin could only block the inhibitory effect of lateral habenula electrical stimulation on some of the cells of the dorsal raphe in the rat. This suggests that a substantial proportion of the inhibitory influence of the lateral habenula on dorsal raphe 5-HT cells does not involve GABAergic mechanisms. In fact, besides GABA, substance $P$ may be involved in the control exerted by the lateral habenula over dorsal raphe 5-HT cells. This is evident from the significant loss of substance P-like immunoreactivity seen in the rat dorsal raphe following lesions of the lateral habenula (Neckers et al., 1979; Vincent et al., 1980). A control of dorsal raphe 5-HT cells by substance $P$ neurons also may occur in the cat since we observed that direct application of substance $P$ into the dorsal raphe could inhibit $\left[{ }^{3} \mathrm{H}\right] 5-\mathrm{HT}$ release in both substantiae nigra to the same extent as picrotoxin application into the lateral habenula. Furthermore, under both conditions, no changes in $\left[{ }^{3} \mathrm{H}\right] 5-\mathrm{HT}$ release were found in either caudate nucleus. However, in marked contrast to that observed under blockade of GABA transmission in the lateral habenula, picrotoxin co-administration to the dorsal raphe did not block the peptide-induced inhibition of nigral $\left[{ }^{3} \mathrm{H}\right] 5-\mathrm{HT}$ release. These results indicate that substance $P$ lateral habenula-dorsal raphe neurons do not mediate the inhibitory effects on nigral $\left[{ }^{3} \mathrm{H}\right] 5-\mathrm{HT}$ release induced by blockade of GABA transmission in the cat lateral habenula. They also may suggest that the picrotoxin-resistant inhibitory effect of the lateral habenula electrical stimulation on dorsal raphe 5 -H'T cells observed in the rat by Stern et al. (1981) could be mediated by substance $P$ neurons.

The action of substance $P$ on the 5-HT cells innervating the substantia nigra could be direct or mediated via inhibitory non-GABAergic interneurons. The decreased release of $\left[{ }^{3} \mathrm{H}\right] 5-\mathrm{H}^{\prime} \mathrm{T}$ in the substantia nigra induced by substance $P$ could suggest a direct inhibitory influence of the peptide on the activity of dorsal raphe 5-HT cells. Although substance $P$ generally is considered an excilatory transmitter, it has been found to inhibit the facilitatory action of acetylcholine on Renshaw cells in the spinal cord (Ryall and Belcher, 1977). Thus, substance $P$ could act directly upon 5 -HT cells by blocking the action of a tonic facilitatory influence on dorsal raphe 5-HT neurons. In addition, substance $\mathrm{P}$ may increase directly or indirectly 5-HT release either from dendrites or collaterals (Wang and Aghajanian, 1977b; Felten and Harrigan, 1980) in the raphe which then could act to inhibit 5-HT neuronal activity and nigral 5-HT release. In fact, a significant increase in $\left[{ }^{3} \mathrm{H}\right] 5-\mathrm{HT}$ release was observed in the dorsal raphe during the local application of substance $\mathrm{P}$ and we have shown previously that the local application of 5-HT in the dorsal raphe decreases nigral 5-HT release (Bourgoin et al., 1981).

It is particularly interesting to note that the application of substance $\mathrm{P}$ to the dorsal raphe or of picrotoxin to the lateral habenula decreased $\left[{ }^{3} \mathrm{H}\right] 5-\mathrm{HT}$ release in the substantia nigra but not in the caudate nucleus. This is surprising in light of anatomical studies indicating that the striatum is innervated by dorsal raphe 5-HT neurons (Bobillier et al., 1976; 'Taber Pierce et al., 1976; Parent et al., 1981; Steinbusch, 1981) and according to results obtained in the rat that the majority of dorsal raphe 5-HT cells which innervate the substantia nigra send collaterals to the ipsilateral striatum (Van der Kooy and Hattori, 1980a). Thus, our findings could suggest that the fine organization of 5-HT projections originating from the dorsal raphe and projecting to the caudate nucleus and the substantia nigra is not entirely similar in the cat and the rat. However, changes in 5-HT neuronal activity in the dorsal raphe do not necessitate an alteration in 5-HT transmission in the caudate nucleus. Indeed, we have reported previously that light and auditory stimulation which increased the firing rate of dorsal raphe neurons in the cat (Jacobs et al., 1980) elevated nigral but not striatal $\left[{ }^{3} \mathrm{H}\right] 5-\mathrm{HT}$ release in "encéphale-isolé" cats (Reisine et al., 1982a). It also should be noted that Speciale et al. (1980) found in rats that bilateral lesions of the lateral habenula, while increasing 5-HT turnover in the dorsal raphe, had no effect on striatal 5-HT turnover. This is reminiscent of our present results since the application of either picrotoxin to the lateral habenula or substance $\mathrm{P}$ to the dorsal raphe increased $\left[{ }^{3} \mathrm{H}\right] 5-\mathrm{HT}$ release in the dorsal raphe but did not change the release of the ${ }^{3} \mathrm{H}$-indoleamine in the caudate nucleus. Thus, it is conceivable that 5 -HT neurons innervating the substantia nigra are, under certain conditions, regulated differently from those projecting to the caudate nucleus. Substance $P$ neurons which project to the dorsal raphe and GABAergic neurons which innervate the lateral habenula may contribute directly or indirectly to this differential control. Other neurons, either originating from the lateral habenula or passing through this structure, may also regulate the activity of dorsal raphe 5-HT neurons projecting to the caudate nucleus and/or the substantia nigra. Indeed, electrical stimulation of the lateral habenula reduced the activity of a large majority of dorsal raphe cells (Wang and Aghajanian, 1977a; Stern et al., $1981)$ and also inhibited $\left[{ }^{3} \mathrm{H}\right] 5-\mathrm{HT}$ release in both the substantia nigra and the caudate nucleus. Of interest, regarding this latter condition and in contrast with that observed during the application of picrotoxin to the lateral habenula or that of substance $P$ to the dorsal raphe, electrical stimulation of the lateral habenula decreased $\left[{ }^{3} \mathrm{H}\right] 5-\mathrm{HT}$ release in the dorsal raphe.

Information reaching the median raphe also could contribute to the changes in $\left[{ }^{3} \mathrm{H}\right] 5-\mathrm{HT}$ release observed in the substantia nigra under our experimental conditions. In fact, it is well established in the rat and the cat that the median raphe innervates the substantia nigra (Bobillier et al., 1976; Dray et al., 1978) and that it receives an input from the habenula (Akagi and Powell, 1968; Herkenham and Nauta, 1979). Furthermore, in the rat, electrical stimulation of the lateral habenula suppresses cell firing in this raphe nucleus (Stern et al., 1981). However, some evidence argues against the selective mediation of the median raphe in the changes in 
$\left[{ }^{3} \mathrm{H}\right] 5$-HT release seen in our study. Changes in $\left[{ }^{3} \mathrm{H}\right] 5$ $\mathrm{HT}$ release in the basal ganglia were always associated with modifications of $\left[{ }^{3} \mathrm{H}\right] 5-\mathrm{HT}$ release in the dorsal raphe. In addition, the effects of picrotoxin application into the lateral habenula on nigral $\left[{ }^{3} \mathrm{H}\right] 5-\mathrm{HT}$ release were blocked by the simultaneous delivery of the GABA antagonist into the dorsal raphe. Studies made in the rat are also in favor of a preferenitial involvement of the dorsal raphe since lesions of the lateral habenula, which decrease substance P levels and augment 5-HT turnover in the dorsal raphe, do not affect these biochemical parameters in the median raphe (Neckers et al., 1979; Speciale et al., 1980).

In the present study, it was observed that the unilateral manipulations involving the lateral habenula could produce changes in $\left[{ }^{3} \mathrm{H}\right] 5$-HT release in both ipsilateral and contralateral structures. Anatomical studies in rats have suggested that the lateral habenula sends cross-projections to the raphe (Herkenham and Nauta, 1979). Furthermore, dorsal raphe 5-HT cells have been shown to project either to the ipsilateral or to the contralateral caudate nucleus and substantia nigra (Jacobs et al., 1978; Van der Kooy and Hattori, 1980b). Although extrapolations from one animal species to another have to be done with caution, these data provide an anatomical support which could explain the control exerted by the lateral habenula on 5-H'l release in both basal ganglia of the cat.

Both the caudate nucleus and the substantia nigra are linked closely to the entopeduncular nucleus which is an output center for the basal ganglia (Wooten and Collins, 1981). As demonstrated in the rat and the cat, this nucleus sends a projection to the lateral habenula, selectively entering the lateral part of this region (Herkenham and Nauta, 1977; Larsen and McBride, 1979; McBride, 1981) which, according to results obtained in the rat, is GABAergic (Nagy et al., 1978). Since, in the present study, the cannula tip placements were preferentially in the most lateral part of the lateral habenula, it is possible that some of the actions of the entopeduncular-habenula pathway were blocked by the picrotoxin application. Furthermore, it has been shown that lesion (Wooten and Collins, 1981) or electrical stimulation (H. Savaki, personal communication) of the substantia nigra selectively affect glucose utilization in the entopeduncular nucleus and in the lateral part of the lateral habenula. Therefore, taken together, these results and our present findings support the role of the lateral habenula in mediating a feedback control of dorsal raphe 5-HT neurons from information arising from the basal ganglia. The specific complexities involved, however, in this regulation remain to be elucidated.

\section{References}

Akagi, K., and E. W. Powell (1968) Differential projections of habenular nuclei. Exp. Neurol. 182: 263-274.

Belin, M. F., M. Aguera, M. Tappaz, A. McRae-Degueurce, P. Bobillier, and J. F. Pujol (1979) GABA-accumulating neurons in the nucleus raphe dorsalis and periaqueductal gray in the rat. A biochemical and autoradiographic study. Brain Res. 170: 279-297.

Bobillier, P., S. Seguin, F. Petitjean, D. Salvert, M. Touret, and
M. Jouvet (1976) The raphé nuclei of the cat brain stem: A topographical atlas of their projections as revealed by autoradiography. Brain Res. 113: 449-486.

Bourgoin, S., P. Soubrié, F. Artaud, T. D. Reisine, and J. Glowinski (1981) Control of 5-HT release in the caudate nucleus and the substantia nigra of the cat. J. Physiol. (Paris) 77: 303-307.

Dray, A., J. Davies, N. R. Oakley, P. Tongroach, and S. Velluchi (1978) The dorsal and medial raphe projections to the substantia nigra in the rat: Electrophysiological, biochemical and behavioral observations. Brain Res. 151: 431-442.

Felten, D. L., and P. Harrigan (1980) Dendrite bundles in nuclei raphé dorsalis and centralis superior of the rabbit. A possible substrate for local control of serotonergic neurons. Neurosci. Lett. 16: 275-280.

Gottesfeld, Z., D. B. Hoover, E. A. Muth, and D. M. Jacobowitz (1978) Lack of biochemical evidence for a direct habenuloraphé GABAergic pathway. Brain Res. 141: 353-356.

Herkenham, M., and W. J. H. Nauta (1977) Afferent connections of the habenula nuclei in the rat. A horseradish peroxidase study with a note on the fiber-of-passage problem. J. Comp. Neurol. 173: 123-146.

Herkenham, M., and W. J. H. Nauta (1979) Efferent connections of the habenular nuclei in the rat. J. Comp. Neurol. 187: $19-48$.

Héry, F., and J. P. Ternaux (1981) Regulation of release processes in central serotoninergic neurons. J. Physiol. (Paris) 77: 287-301.

Héry, F., G. Simonnet, S. Bourgoin, P. Soubrié, F. Artaud, M. Hamon, and J. Glowinski (1979) Effect of nerve activity on the in vivo release of ${ }^{3} \mathrm{H}$-serotonin continuously formed from $\mathrm{L}-{ }^{3} \mathrm{H}$-tryptophan in the caudate nucleus of the cat. Brain Res. 169: $317-334$.

Jacobs, B. I., S. I. Foote, and F. F. Bloom (1978) Differential projections of neurons within the dorsal raphe nucleus of the rat: A horseradish peroxidase (HRP) study. Brain Res. 147: 149-153.

Jacobs, B. L., M. F. Trulson, and J. Heym (1980) Raphé unit activity in freely moving cats. I. Effect of sensory stimulation. Soc. Neurosci. Abstr. 6: 234.

Larsen, K. D., and R. L. McBride (1979) The organization of feline entopeduncular nucleus projections: Anatomical studies. J. Comp. Neurol. 184: 293-308.

McBride, R. L. (1981) Organization of afferent connections of the feline lateral habenular nucleus. J. Comp. Neurol. 198: 89-99.

Nagy, J. I., D. A. Carter, J. Lehmann, and H. C. Fibiger (1978) Evidence for a GABA containing projection from the entopeduncular nucleus to the lateral habenula in the rat. Brain Res. 145: 360-364.

Neckers, L. M., J. P. Schwartz, R. J. Wyatt, and S. G. Speciale (1979) Substance $P$ afferents from the habenula innervate the dorsal raphé nucleus. Exp. Brain Res. 37: 619-623.

Parent, A., L. Descarries, and A. Beaudet (1981) Organization of ascending serotonin systems in the adult rat brain. A radioautographic study after intraventricular administration of ${ }^{3} \mathrm{H}$-5-hydroxytryptamine. Neuroscience $6: 115-138$.

Reisine, T., P. Soubrié, F. Artaud, and J. Glowinski (1982a) Sensory stimuli differentially affect in vivo nigral and striatal ${ }^{3} \mathrm{H}$-serotonin release in the cat. Brain Res. 232: 77-87.

Reisine, T., P. Soubrié, F. Artaud, and J. Glowinski (1982b) Application of L-glutamic acid and substance $P$ to the substantia nigra modulates in vivo $\left[{ }^{3} \mathrm{H}\right]$ serotonin release in the basal ganglia of the cat. Brain Res. 236: 317-327.

Ryall, R. W., and G. Belcher (1977) Substance P selectively blocks nicotinic receptor on Renshaw cells: A possible synaptic inhibitory mechanism. Brain Res. 137: 376-380.

Sakai, K., P. Salvert, M. Touret, and M. Jouvet (1977) Afferent 
connections of the nucleus raphe dorsalis in the cat as visualized by the horseradish peroxidase technique. Brain Res. 137: 11-35.

Snider, R. A., and W. T. Niemer (1961) A Stereotaxic Atlas of the Cat Brain, University of Chicago Press, Chicago.

Soubrié, P., J. L. Montastruc, S. Bourgoin, T. Reisine, F. Artaud, and J. Glowinski (1981a) In vivo evidence for GABAergic control of serotonin release in the cat substantia nigra. Eur. J. Pharmacol. 69: 483-488.

Soubrié, P., T. Reisine, F. Artaud, and J. Glowinski (1981b) Role of the lateral habenula in modulating nigral and striatal in vivo $\left({ }^{3} \mathrm{H}\right)$ serotonin release in the cat. Brain Res. 222: 192 197.

Speciale, S. G., L. M. Neckers, and R. J. Wyatt (1980) Habenular modulation of raphé indoleamine metabolism. Life Sci. 27: 2367-2372.

Steinbusch, H. W. M. (1981) Distribution of serotonin-immunoreactivity in the central nervous system of the rat-cell bodies and terminals. Neuroscience 6 : 557-618.

Stern, W. C., A. Johnson, J. D. Bronzino, and P. J. Morgane (1979) Effects of electrical stimulation of the lateral habenula on single-unit activity of raphé neurons. Exp. Neurol. 65: 326-342.

Stern, W. C., A. Johnson, J. D. Bronzino, and P. J. Morgane (1981) Neuropharmacology of the afferent projections from the lateral habenula and substantia nigra to the anterior raphé in the rat. Neuropharmacology 20: 974-979.

Taber Pierce, E., W. E. Foote, and J. A. Hobson (1976) The efferent connection of the nucleus raphe dorsalis. Brain Res. 107: 137-144.

Van der Kooy, D., and T. Hattori (1980a) Dorsal raphe cells with collateral projections to the caudate-putamen and substantia nigra: A fluorescent retrograde double labeling study in the rat. Brain Res. 186: 1-7.

Van der Kooy, D., and T. Hattori (1980b) Bilaterally situated dorsal raphé cell bodies have only unilateral forebrain projections in rat. Brain Res. 192: 550-554.

Vincent, S. R., W. A. Staines, E. G. McGeer, and H. C. Fibiger (1980) Transmitters contained in the efferents of the habenula. Brain Res. 125: 479-484.

Wang, R. Y., and G. K. Aghajanian (1977a) Physiological evidence for habenula as major link between forebrain and midbrain raphé. Science 197: 89-91.

Wang, R. Y., and G. K. Aghajanian (1977b) Antidromically identified serotonergic neurons in the rat midbrain raphé: Evidence for collateral inhibition. Brain Res. 132: 186-193.

Wooten, G. F., and R. C. Collins (1981) Metabolic effects of unilateral lesion of the substantia nigra. J. Neurosci. 1: 285291. 